\title{
Interindividual variation in relationships between plasma heparin concentration and the results of five heparin assays
}

Citation for published version (APA):

van Putten, J., van de Ruit, M., Beunis, M., \& Hemker, H. C. (1982). Interindividual variation in relationships between plasma heparin concentration and the results of five heparin assays. Clinica Chimica Acta, 122(2), 261-270. https://doi.org/10.1016/0009-8981(82)90285-6

Document status and date:

Published: 01/07/1982

DOI:

10.1016/0009-8981(82)90285-6

Document Version:

Publisher's PDF, also known as Version of record

Please check the document version of this publication:

- A submitted manuscript is the version of the article upon submission and before peer-review. There can be important differences between the submitted version and the official published version of record.

People interested in the research are advised to contact the author for the final version of the publication, or visit the DOI to the publisher's website.

- The final author version and the galley proof are versions of the publication after peer review.

- The final published version features the final layout of the paper including the volume, issue and page numbers.

Link to publication

\footnotetext{
General rights rights.

- You may freely distribute the URL identifying the publication in the public portal. please follow below link for the End User Agreement:

www.umlib.nl/taverne-license

Take down policy

If you believe that this document breaches copyright please contact us at:

repository@maastrichtuniversity.nl

providing details and we will investigate your claim.
}

Copyright and moral rights for the publications made accessible in the public portal are retained by the authors and/or other copyright owners and it is a condition of accessing publications that users recognise and abide by the legal requirements associated with these

- Users may download and print one copy of any publication from the public portal for the purpose of private study or research.

- You may not further distribute the material or use it for any profit-making activity or commercial gain

If the publication is distributed under the terms of Article $25 \mathrm{fa}$ of the Dutch Copyright Act, indicated by the "Taverne" license above, 


\title{
Interindividual variation in relationships between plasma heparin concentration and the results of five heparin assays
}

\author{
Janjaap van Putten *, Marjo van de Ruit, Marlène Beunis \\ and $\mathrm{H}$. Coenraad Hemker ** \\ Department of Clinical Chemistry, Stichting Samenwerking Delftse Ziekenhuizen, Delft (The Netherlands) \\ (Received December 4th, 1981; revision March 1st, 1982)
}

\section{Summary}

In order to determine their value for estimating the heparin concentration in plasma, we established the relationship between test result and heparin concentration in plasma from various individuals, for five assays used with heparin treatment. Only assays which can be carried out routinely in clinical laboratories were considered. The thrombin time and the whole blood recalcification time give pointless and ambiguous information respectively, concerning the heparin level. The activated partial thromboplastin time with and without heparin neutralisation give only a rough estimate. The spectrophotometric method using a chromogenic substrate gives the best information. The latter can be improved by using a non-linear (parabolic) equation for the calculation of the reference curve. Current heparin therapy, controlled with the aid of a clotting assay, may result in plasma heparin concentrations that vary widely from one patient to another.

\section{Introduction}

Since the aim of heparin therapy is to abolish inappropriate clotting, the dose of heparin is usually based on the result of a clotting assay. Often, this assay gives the physician insufficient information to prevent the risk of an inadequate or excessive dose, resulting in thrombosis or haemorrhage. The probability of haemorrhage during heparin therapy has been reported to correlate better with the heparin concentration than with the clotting potency of heparinised plasma [1]. Therefore

* Correspondence should be addressed to J.J. van Putten, Department of Clinical Chemistry, SSDZ, P.O. Box 5010, 2600 GA Delft, The Netherlands.

** Department of Biochemistry, Rijks Universiteit Limburg, Maastricht, The Netherlands. 
one should be able to estimate these levels with an acceptable degree of precision.

The relationship between heparin dose and heparin plasma level, as well as the relationship between heparin plasma level and therapeutic or prophylactic effect can be determined only by means of a clinical trial. A heparin determination, that is accurate and easy to perform in clinical laboratories, is a prerequisite for such a trial. Titration methods and clotting assays employing the anti-Xa activity are too laborious. Other available heparin assays used for establishing the dose of heparin do not give insight into either of the relationships mentioned above. Knowledge of the plasma heparin level is essential for this; therefore, a suitable assay is mandatory.

The purpose of this investigation was to determine the inter-individual variation in the relationship between heparin concentration and its effect on the outcome of several assays. The following methods were investigated: thrombin time (TT), whole blood recalcification time (RCT), activated partial thromboplastin time (APTT), APTT with heparin neutralisation (APTTHN) and a chromogenic substrate method (CSM).

\section{Materials and methods}

\section{Blood samples}

From 11 arbitrarily chosen out-patients, not receiving heparin and showing no abnormalities in a routine check of haematological and clotting measurements, 4 tubes of venous blood were collected by means of a vacuum system. The first tube (Venoject, purple stopper, $2.7 \mathrm{ml}, 3.3 \mathrm{mg}$ di-K-EDTA) was used for haematocrit determination with a Coulter Counter $\mathrm{S}+$. The next 3 tubes (Venoject, black stopper, $4.5 \mathrm{ml}, 3.8 \%$ Tri-Na-citrate) were used for the other tests.

\section{Heparin}

Heparin was obtained from Leo, Emmen, Holland. According to the manufacturer, the solution contained 5000 USP U $/ 1$ of the sodium salt. Dilutions were made in $0.154 \mathrm{~mol} / 1 \mathrm{NaCl}$.

To each of 7 tubes, containing $50 \mu 1$ diluted heparin solution, $950 \mu 1$ of citrated blood were added. The heparin concentrations were chosen to make final concentrations of 0 and approximately 50,150,300, 600 and $800 \mathrm{U}$ of heparin/1 blood. For the citrate blood (RCT) and citrated plasma (all other assays), the exact plasma heparin concentration was calculated from the haematocrit. We obtained heparin levels of approximately $100,250,500,1000$ and $1500 \mathrm{U} / 1$ plasma.

\section{Platelet poor plasma}

This was obtained by centrifugation of the 7 citrated blood tubes $(10 \mathrm{~min}$, $3500 \times \mathrm{g}$, room temperature). This yielded less than $3 \times 10^{9}$ platelets $/ 1$.

The following assays were performed in duplicate at $37^{\circ} \mathrm{C}$, within $3 \mathrm{~h}$ of venepuncture.

$R C T$

The clotting time was measured after adding $200 \mu 1$ citrated blood to $200 \mu 1$ 
pre-warmed calcium chloride $(0.32 \mathrm{~mol} / \mathrm{l})$ in a glass tube. This tube was tilted every $15 \mathrm{~s}$. The end-point was the first observation by the medical technologist of a clot in the tilted tube.

\section{$T T$}

The clotting time was measured after mixing $100 \mu \mathrm{l}$ thrombin $(3 \mathrm{E} / \mathrm{ml}$, Roche) with $200 \mu 1$ pre-warmed plasma in a plastic tube. The end-point was the automatic registration of a fibrin thread by the 'coagulometer' (Salm en Kipp), testing every $0.5 \mathrm{~s}$.

\section{APTT}

For the APTT, $100 \mu 1$ plasma were incubated for $3 \mathrm{~min}$ at $37^{\circ} \mathrm{C}$ with $200 \mu 1$ cephalin-kaolin reagent (Diagen). The clotting time was measured after addition of $100 \mu 1$ calcium chloride $(0.025 \mathrm{~mol} / 1)$. The end-point was the same as for the TT.

\section{APTTNH}

This was performed as described by Hoffmann and Meulendijk [2]. The APTT was repeated after the heparin level had been increased by a known value. Then it was performed again after neutralising the heparin with $10 \mu \mathrm{g}$ hexadimethrine bromide per assay (Polybrene, Sigma Chemical Co.).

\section{CSM}

This was performed as described by Teien and Lee [3], with some minor modifications. In a glass cuvette of a programmable analyser (PA800 Vitraton), 50 $\mu 1$ plasma $(1+9$ diluted with Michaelis buffer) were incubated with $350 \mu 1$ factor $\mathrm{Xa}$ ( 7 nkatal $/ \mathrm{ml}$ buffer, Kabi). The Xa buffer ( $\mathrm{pH} 8.4$ and I 0.2) contained di-K-EDTA (75 mmol/1), Tris- $\mathrm{HCl}(50 \mathrm{mmol} / \mathrm{l})$ and $\mathrm{NaCl}(175 \mathrm{mmol} / 1)$. After $3 \mathrm{~min} 40 \mathrm{~s}, 100$ $\mu 1$ substrate-solution $(0.2 \mathrm{mmol} / 1 \mathrm{~S}-2222 \mathrm{Kabi})$ were added and the rate of change of extinction at $405 \mathrm{~nm}$ was determined for $20 \mathrm{~s}$. With a series of known heparin concentrations in pooled human plasma, reference measurements were performed. By the method of least squares a linear reference curve was calculated from these measurements. Unknown heparin levels were read from this curve. Alternatively, a parabolic reference curve was used for the calculation (see below).

\section{Statistics}

Bartlett's test was applied to test the homogeneity of the variances at different heparin levels. If inhomogeneity was proven, the logarithms of the data were used, as these proved to be more homogenous. The experimental variances $\left(\mathrm{S}_{\text {exp }}^{2}\right)$ of three assays (RCT, APTT, CSM) were calculated from the results of duplicate experiments. The pooled inter-individual variances $\left(\mathrm{S}_{\text {int }}^{2}\right)$ of the test results at three heparin levels were calculated using one-way analysis of variance [4]. $\mathrm{S}_{\text {int }}^{2}$ was compared with $\mathrm{S}_{\exp }^{2}$ (divided by 2 , since the mean of the duplicates were used) by means of Fisher's test. The differences in the means of the test results at the three heparin concentrations were compared with $\mathrm{S}_{\text {int }}^{2}$. 

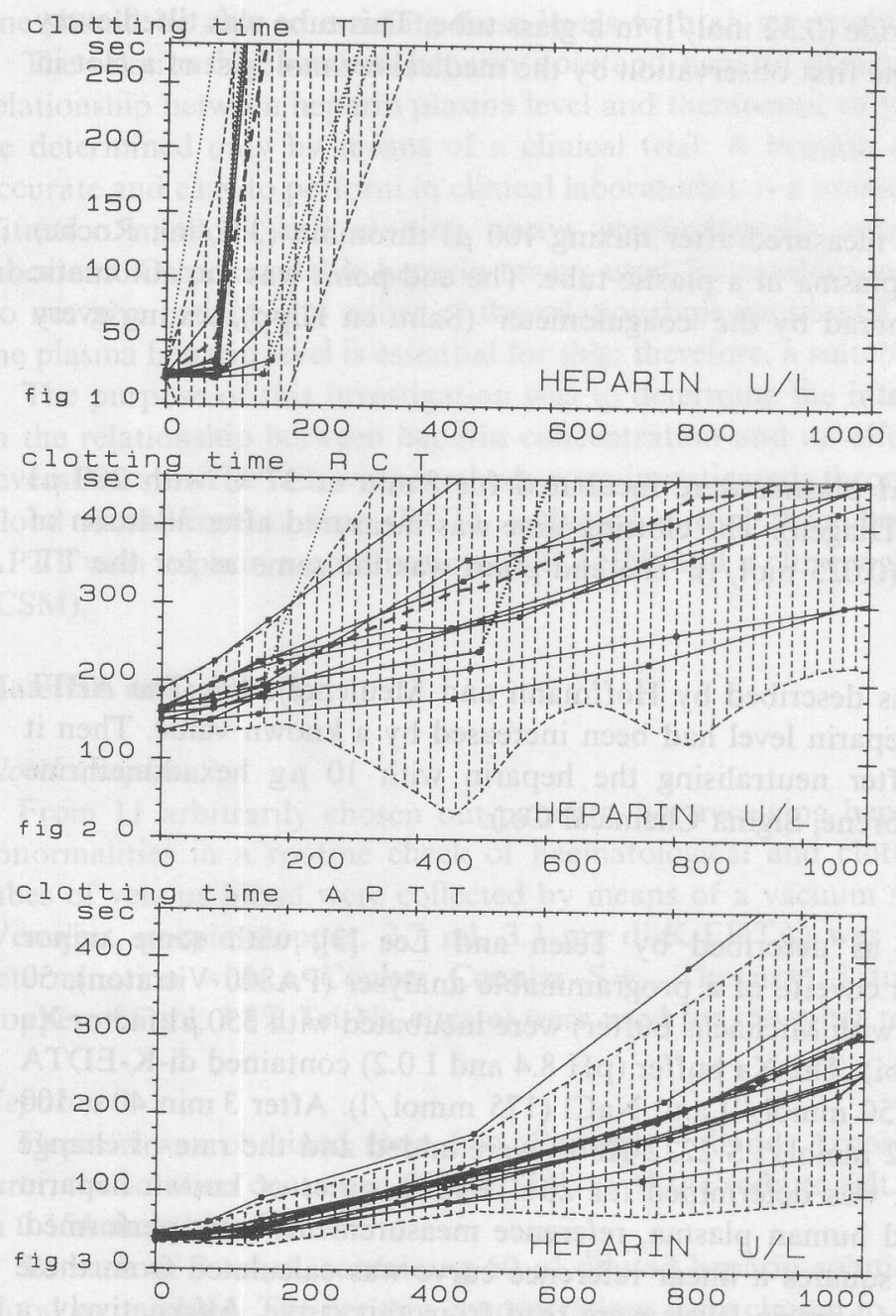

\section{Results}

For each of the 6 methods we used the following procedure to obtain the data presented.

Each test result was plotted against the plasma heparin concentration and data points derived from the same patient were connected by a straight line (these lines represent 2-point interpolation). Then we determined at $20 \mathrm{U} / 1$ intervals, the test result related to heparin concentrations from $0 U / 1$ to the highest available concentration. At each interval we calculated the mean and standard deviation (SD) of the individual test results of the plasmas (these test results are mainly interpolated but never extrapolated). A dashed line represents those mean values (Figs. 1-6). For 

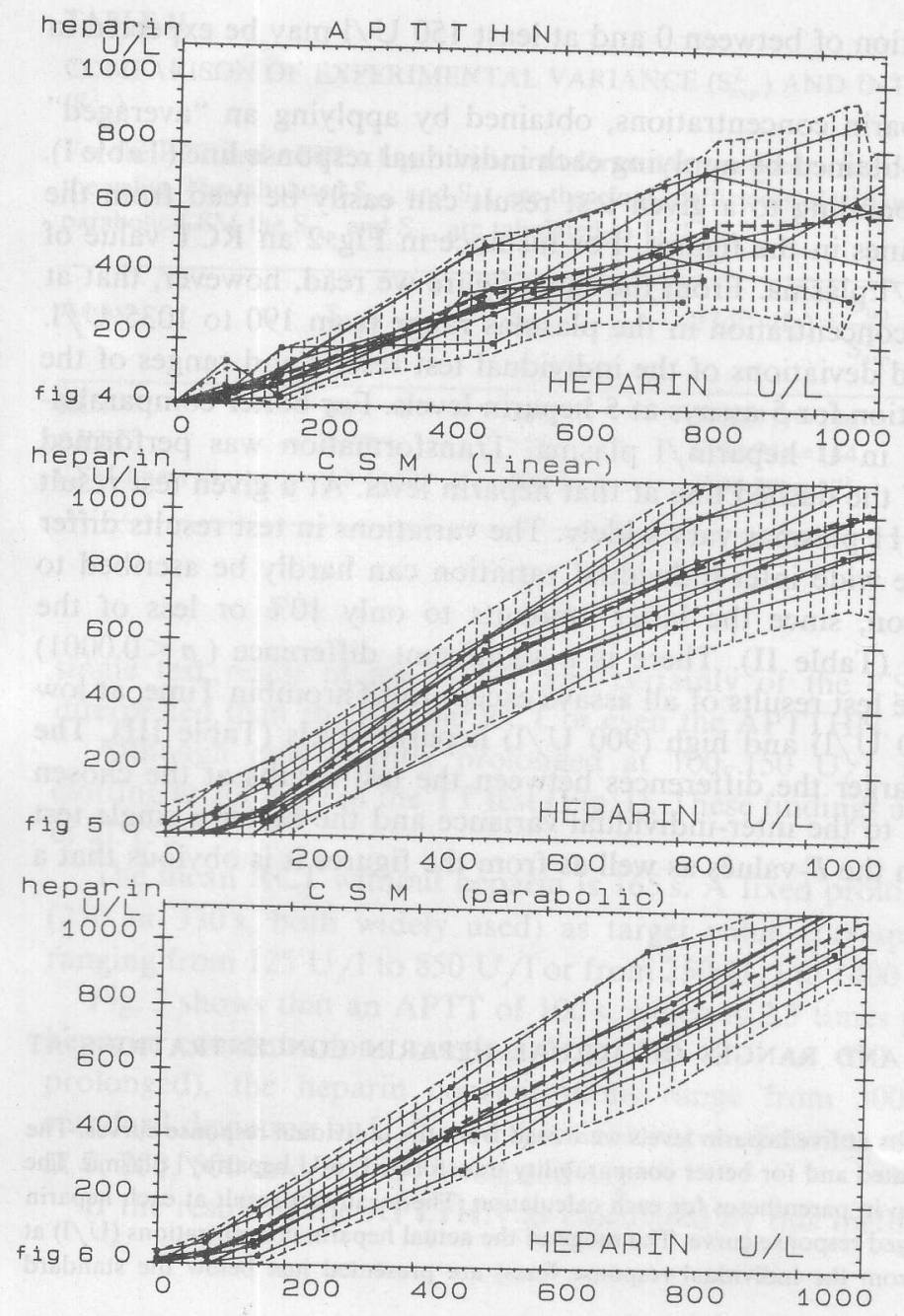

Figs. 1-6. Relationship between plasma heparin concentration and test result. Data derived from the same patient are connected by a solid line. The means of the interpolated data are shown by a dashed line. A dotted line indicates that the plasma failed to clot at the next higher heparin concentrations tested. Fig. 1. Thrombin Time. Fig. 2. Recalcification Time (whole blood). Fig. 3. Activated Partial Thromboplastin Time. Fig. 4. Activated Partial Thromboplastin Time with Heparin Neutralisation. Fig. 5. Chromogenic Substrate Heparin assay with S-2222, applying a linear reference curve. Fig. 6. Chromogenic Substrate Heparin assay with S-2222, applying a parabolic reference curve.

further interpretation we considered this line as an "averaged response" curve. The estimated inter-individual variation in test result is represented by a shaded area (mean $\pm 2 \mathrm{SD})$.

In all figures, except Fig. 2, one may note a shift of the curves to the right of between 0 and $150 \mathrm{U} / \mathrm{l}$. This is presumably due to neutralisation of heparin by 
platelet factor 4. A deviation of between 0 and at least $150 \mathrm{U} / 1$ may be expected in the assays.

We compared the heparin concentrations, obtained by applying an "averaged" response line with those obtained by applying each individual response line (Table I). The heparin level corresponding to a given test result can easily be read from the abscissa via the dashed lines in the figures. For instance in Fig. 2 an RCT value of $295 \mathrm{~s}$ is related to $500 \mathrm{U} / 1$ plasma. From the same figure we read, however, that at $295 \mathrm{~s}$ the actual heparin concentration in the plasmas range from 190 to $1035 \mathrm{U} / \mathrm{l}$. Table I gives the standard deviations of the individual test results and ranges of the actual heparin concentration for 5 assays at 5 heparin levels. For better comparability the SD is presented in $\mathrm{U}$ heparin/1 plasma. Transformation was performed according to the slope of the dashed line at that heparin level. At a given test result the heparin levels in the 11 plasmas vary widely. The variations in test results differ from assay to assay. The wide inter-individual variation can hardly be ascribed to the experimental variation, since the latter amounts to only $10 \%$ or less of the interindividual variation (Table II). There is a significant difference $(p<0.0001)$ between the means of the test results of all assays except the Thrombin Time, at low (150 U/1), medium $(550 \mathrm{U} / \mathrm{l})$ and high $(900 \mathrm{U} / \mathrm{l})$ heparin levels (Table III). The larger the $F$-value, the larger the differences between the test results at the chosen heparin levels compared to the inter-individual variance and the better a single test can be interpreted. From the $F$-values as well as from the figures it is obvious that a

\section{TABLE I}

STANDARD DEVIATION AND RANGES OF ACTUAL HEPARIN CONCENTRATIONS AT FIVE HEPARIN LEVELS

For each method the test results at five heparin levels were read from the individual response curves. The standard deviation was calculated and for better comparability transformed to $U$ heparin $/ 1$ plasma. The number of data points is given in parentheses for each calculation. The mean test result at each heparin level was read from the averaged response curve. The range of the actual heparin concentrations $(\mathbf{U} / 1)$ at this mean test result (read from the individual response lines) are presented just below the standard deviation.

\begin{tabular}{|c|c|c|c|c|c|c|}
\hline \multirow{2}{*}{\multicolumn{2}{|c|}{ Assay }} & \multicolumn{5}{|c|}{ Heparin level } \\
\hline & & $0 \mathrm{U} / \mathbf{1}$ & $300 \mathrm{U} / 1$ & $500 \mathrm{U} / 1$ & $800 \mathrm{U} / 1$ & $1000 \mathrm{U} / 1$ \\
\hline \multirow[t]{2}{*}{$\mathrm{RCT}$} & $\mathrm{SD}(n)$ & $54(11)$ & $185(10)$ & $368 \quad(9)$ & 385 (9) & $390 \quad(9)$ \\
\hline & range & $0-210$ & $110-830$ & $190-1035$ & $305->1400$ & $400-\gg 1400$ \\
\hline \multirow{2}{*}{\multicolumn{2}{|c|}{ APTT }} & $57(11)$ & $85(11)$ & $104(11)$ & $313(11)$ & $265 \quad(8)$ \\
\hline & & $0-155$ & $150-450$ & $290-805$ & $353->1500$ & $640-\gg 1500$ \\
\hline \multicolumn{2}{|l|}{ APTTHN } & $0(11)$ & $62(11)$ & $157(11)$ & 128 & 1000 \\
\hline & & $0-0$ & $235-395$ & $365-800$ & $550->1500$ & $620-\gg 1500$ \\
\hline \multirow{2}{*}{\multicolumn{2}{|c|}{ CSM linear }} & 85 (11) & 55 (11) & $79(11)$ & $153(11)$ & $203(11)$ \\
\hline & & $0-120$ & $200-445$ & $420-675$ & $645-1090$ & $740->1400$ \\
\hline \multirow{2}{*}{\multicolumn{2}{|c|}{ CSM parabolic }} & 31 (8) & $59 \quad(8)$ & 84 (8) & 111 & 83 (8) \\
\hline & & $0-80$ & $220-420$ & $395-605$ & $620-\quad 935$ & $775-1110$ \\
\hline
\end{tabular}


TABLE II

COMPARISON OF EXPERIMENTAL VARIANCE $\left(\mathrm{S}_{\exp }^{2}\right)$ AND INTER-INDIVIDUAL VARIANCE
$\left(\mathrm{S}_{\mathrm{int}}^{2}\right)$

For the RCT and APTT a logarithmic transformation was used, since the individual variance varied with the value. The tabulated $S_{\exp }$ and $S_{\text {int }}$ are therefore coefficients of variance. For the APTTHN, linear and parabolic CSM the $S_{\text {exp }}$ and $S_{\text {int }}$ are tabulated as $U / 1$

\begin{tabular}{lllll}
\hline Assay & $\mathrm{S}_{\text {exp }}$ & $\mathrm{S}_{\text {int }}$ & $F\left(\mathrm{df}_{1}, \mathrm{df}_{2}\right)=\frac{\mathrm{S}_{\text {int }}^{2}}{\mathrm{~S}_{\text {exp }}^{2}}$ & Corresponding $p$-value \\
\hline RCT & $2 \%$ & $22 \%$ & $F(30,71)=196$ & $<0.0001$ \\
APTT & $2.7 \%$ & $27 \%$ & $F(30,72)=164$ & $<0.0001$ \\
CSM linear & $7.6 \mathrm{U} / 1$ & $101 \mathrm{U} / 1$ & $F(30,39)=175$ & $<0.0001$ \\
\hline
\end{tabular}

single test result of the APTT and certainly of the CSM can be more reliably interpreted than the TT, the RCT or even the APTTHN.

Although only slightly prolonged at $100-150 \mathrm{U} / \mathrm{l}$, all plasmas fail to show clotting at $200 \mathrm{U} / 1$ in the TT test (Fig. 1). These findings agree with those of Pizzuto et al. [5].

The mean RCT without heparin is $165 \mathrm{~s}$. A fixed prolongation factor of 1.5 or 2 ( 250 or $330 \mathrm{~s}$, both widely used) as target value corresponds with heparin levels ranging from $125 \mathrm{U} / 1$ to $850 \mathrm{U} / 1$ or from $250 \mathrm{U} / 1$ to $1400 \mathrm{U} / 1$, respectively (Fig. 2).

Fig. 3 shows that an APTT of $100 \mathrm{~s}$, which is 2.5 times prolonged corresponds to heparin concentrations ranging from $200 \mathrm{U} / 1$ to $650 \mathrm{U} / 1$. At $120 \mathrm{~s}$ (3 times prolonged), the heparin concentrations range from $300 \mathrm{U} / 1$ to $850 \mathrm{U} / 1$. The standard deviation in $\mathrm{U} / 1 \mathrm{read}$ from the curve of means is $50,80,100$ and $200 \mathrm{U} / 1$ at $0,250,500$ and $800 \mathrm{U} / 1$, respectively.

If the result of the APTTHN as calculated by this method, lies between $280 \mathrm{U} / 1$

\section{TABLE III}

\section{COMPARISON OF TEST RESULTS AT THREE HEPARIN LEVELS} The means of test results at heparin concentrations of 150,550 and $900 \mathrm{U} / 1$ are compared with
inter-individual variance.

\begin{tabular}{llllll}
\hline Assay & \multicolumn{2}{l}{ Mean value of test result at } & $\begin{array}{l}F(2,30) \\
\text { between }\end{array}$ & $\begin{array}{l}\text { Corresponding } \\
p \text {-value }\end{array}$ \\
\cline { 2 - 4 } & $150 \mathrm{U} / 1$ & $550 \mathrm{U} / 1$ & $900 \mathrm{U} / 1$ & & \\
\hline RCT & $195 \mathrm{~s}$ & $295 \mathrm{~s}$ & $379 \mathrm{~s}$ & 22.6 & $<0.0001$ \\
APTT & $52 \mathrm{~s}$ & $132 \mathrm{~s}$ & $224 \mathrm{~s}$ & 104 & $<0.0001$ \\
APTTHN & $66 \mathrm{U} / 1$ & $372 \mathrm{U} / 1$ & $562 \mathrm{U} / 1$ & 71 & $<0.0001$ \\
CSM linear & $80 \mathrm{U} / 1$ & $580 \mathrm{U} / 1$ & $893 \mathrm{U} / 1$ & 180 & $<0.0001$ \\
CSM parabolic & $66 \mathrm{U} / 1$ & $372 \mathrm{U} / 1$ & $887 \mathrm{U} / 1$ & 190 & $<0.0001$ \\
\hline
\end{tabular}


and $340 \mathrm{U} / 1$ then the actual heparin concentration in these 11 plasmas is between $300 \mathrm{U} / 1$ and $600 \mathrm{U} / 1$. The standard deviation at 0,250 and $500 \mathrm{U} / 1$ is 0,153 and $354 \mathrm{U} / 1$, respectively.

The amidolytic method shows a standard deviation of $63,69,88$ and 127 at $0 \mathrm{U} / 1,250 \mathrm{U} / 1,500 \mathrm{U} / 1$ and $800 \mathrm{U} / 1$, respectively. At test results between $360 \mathrm{U} / 1$ and $650 \mathrm{U} / 1$ no plasma has a concentration over $800 \mathrm{U} / 1$ or under $300 \mathrm{U} / 1$ (Fig. 5). At a result of $975 \mathrm{U} / 1$ the heparin levels range from $750 \mathrm{U} / 1$ to $1500 \mathrm{U} / 1$. Using a parabolic equation for calculating the reference curve the heparin concentrations range from $775 \mathrm{U} / 1$ to $1075 \mathrm{U} / 1$ (Fig. 6).

\section{Discussion}

We investigated the inter-individual variation in test results of assays used to determine dosage of heparin. Therefore we spiked the blood of 11 individuals with known amounts of heparin and determined the plasma heparin concentration using five different methods. Relatively few attempts have been made to define an optimal therapeutic or prophylactic heparin concentration. In general, levels between 50 and $200 \mathrm{U} / 1$ plasma are considered to be prophylactic and levels between 300 and 800 $\mathrm{U} / 1$ plasma to be therapeutic. The results of a heparin assay should therefore give sufficient information to differentiate plasmas containing $0,300,500,800$, and 1000 $\mathrm{U} / 1$, respectively. Considering heparin concentrations of 150,550 and $900 \mathrm{U} / 1$ inadequate, sufficient and excessive respectively, we evaluated the usefulness of 5 assays. A good assay allows an unambiguous classification into these groups, without variation between patients.

In neither the prophylactic $(0-200 \mathrm{U} / \mathrm{l})$ nor the therapeutic range (300-800 U/1) does the TT give useful information about the heparin level. As a routine laboratory determination for testing a heparin concentration, the TT gives pointless and the RCT gives ambiguous information. The former only reveals whether the heparin concentration is above or below $250 \mathrm{U} / 1$, approximately; the latter gives no useful information, due to the wide variation in the response of different plasmas. Use of the RCT as a routine check in heparin therapy may lead to dangerous clinical sequelae and must therefore be strongly discouraged.

The APTT gives sufficient information to monitor patients at $300 \mathrm{U} / \mathrm{l}$, but an overdose (above $1000 \mathrm{U} / 1$ ) can easily be missed. In normal subjects, the relationship between heparin concentration and its effect on the APTT can be estimated from haematocrit and base-line APTT [6]. It is not practical to use the pre-heparin clotting value as a base-line value, since the majority of patients treated with heparin are surgical cases. During operations the blood loss, clotting, infusion of blood, plasma or saline will alter the haematocrit and the concentrations of clotting factors. Following surgery one would not wish to leave a patient untreated simply to determine a base-line value. Even with 11 subjects it is clear that at a given test result the actual heparin concentration is rather unpredictable. (A result of $140 \mathrm{~s}$ indicates $290 \mathrm{U} / 1$ in one plasma, but $805 \mathrm{U} / 1$ in another.)

The result of the APTTHN is expressed in U heparin/1 plasma as described by Hoffmann and Meulendijk [2]. This method assumes a linear relationship between 
the APTT $(\mathrm{s})$ and the heparin concentration $(\mathrm{U} / \mathrm{l})$ starting from $0 \mathrm{U} / 1$. Due to the shift in the range from $0 \mathrm{U} / 1$ to $200 \mathrm{U} / 1$ mentioned above, this assumption appears to be incorrect. For the APTT, 3 out of 11 plasmas did not clot at all at $1000 \mathrm{U} / 1$ (Fig. 3). Unfortunately, this fact made it impossible to calculate the heparin concentration by means of the APTTHN at $800 \mathrm{U} / 1$. Hoffmann and Meulendijk [2] had the same problem as can be deduced from their Fig. 2B. Therefore this method is of
limited use.

The heparin assay with chromogenic substrates and an automatic analyser, offers little more than the APTT. Especially at results above $800 \mathrm{U} / 1$ this CSM lacks reliability. This is partly due to the non-rectilinearity of the reference plot (not shown), as previously reported [7]. The logical consequence is to fit a parabola through the reference points, resulting in essentially more accurate readings. The results of this modification are shown in Fig. 6 (CSM parabolic). This CSM matched the demands of an acceptable heparin assay as mentioned above.

Still, using the CSM (parabolic) we found a standard deviation of $31 \mathrm{U} / 1$ in samples without heparin and a standard deviation of $111 \mathrm{U} / 1$ in samples containing $800 \mathrm{U} / 1$. Choosing any one of the individual calibration lines instead of the "averaged" reference curve would lead to the same conclusion of wide variations. This important inter-individual variation may be caused by the influence of variations in the amount of platelet factor $4(\mathrm{pf} 4)$ as well as by the influence of varying levels of antithrombin III (AtIII). Whether the test outcome should be corrected for deviating AtIII levels, remains to be investigated. The procedures for collecting blood and preparing plasma cause pf4 release to a variable extent and may therefore introduce a considerable error in heparin determination, due to neutralisation of part of the heparin by this pf4 [3]. It also remains to be investigated whether and how this can be avoided in the clinical laboratory.

Currently, a fixed prolongation of clotting time (APTT) is used as a target value for heparin therapy, rather than heparin concentration. This prolongation may be expressed in seconds or as a ratio with respect to a reference value. The target value may vary between laboratories, but in each hospital it is fixed and mostly patient-independent. The results of our investigation clearly demonstrate that this regimen may result in plasma heparin concentrations, which vary widely from one patient to
the other.

\section{Acknowledgement}

The authors wish to thank P.M.M. van Haard, Ph.D. and E.A. Sluyter M.D. for their critical and helpful assistance in translating the manuscript.

\section{References}

1 Holm HA. Heparin concentration (S-2222) and effect of heparin treatment. In:Lijnen HR, Collen D, Herstraete M, eds. Developments in haematology. The Hague, Martinus Nijhof: 1980; 1: 63-69.

Hoffmann JJML, Meulendijk PN. Plasma heparin: A simple, one-sample determination of both effect
and concentration based on the activated partial thromboplastin time Clin $417-424$. 
3 Teien AN, Lee M. Evaluation of an amidolytic heparin assay method. Thromb Res 1977; 10: 399-410.

4 Snedecor GW, Cochran WG. Statistical methods. Iowa U.S.A., The Iowa State University Press, 1973; 6 th ed.

5 Pizzuto J, Garcia-Medez S, de la Paz Reyna M, et al. Thrombin time dilution test: A simple method for the control of heparin therapy. Thromb Hemostas 1979; 42: 1276-1285.

6 Whitfield LR, Levy G. Relationship between concentration and anticoagulant effect of heparin in plasma of normal subjects. Clin Pharmacol 1980; 28: 509-516.

7 Aiach M, Nussas C, Mardiguian J. Effect of some experimental conditions on the activity of a low molecular weight heparin fraction compared to a high molecular weight fraction. Thromb Hemostas 1981; 46: 236. 